
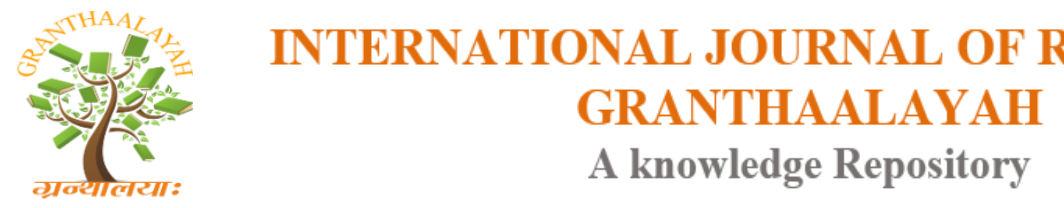

Management

\title{
FINANCIAL INCLUSION: A PRELUDE TO ECONOMIC STATUS OF VULNERABLE GROUP
}

\author{
Dr. Mukesh Kumar Sharma *1 \\ ${ }^{* 1}$ Assistant Professor, School of Management, Raffles University, Neemrana, India
}

DOI: https://doi.org/10.29121/granthaalayah.v4.i12.2016.2403

\begin{abstract}
India is a country where a sizeable amount of population lives in rural areas. They are engaged in agriculture and allied activities. Most of the people living in rural areas are poor. They do not have any access to the banks. The awareness and access of the poor to the banking services is important for the alleviation of the poverty. Their access to the banking services will contribute a lot to the growth and development of our country's economy. Financial inclusion is a great weapon to overcome the financial backwardness as well as the establishment of good governance. It broadens the resource base of the financial system by developing a culture of savings among large segment of rural population, disadvantaged group and plays an essential role in the process of economic development. The Government of India and the Reserve Bank of India (RBI) have been making concentrated efforts periodically to overcome such vicious problems by promoting Financial Inclusion, being one of the important national objectives of the country. Since first phase of nationalization (1969) GoI continuously promoting financial inclusion through self-help groups, no frills account, simplification of KYC, Business correspondents etc., but no palpable effect could be seen in the plight of these financially vulnerable people. To mitigate this long drawn financial sufferings, Prime Minister Narendra Modi announced a new scheme in his Independence Day speech on 15th Aug 2014 called Pradhan Mantri Jan Dhan Yojana (PMJDY). Mission of PMJDY is to ensure easy access of financial services for the excluded section i.e. weaker section and the low income group. This effort will certainly go a long way in promoting economic growth and reducing poverty, while mitigating systematic risk and maintaining financial stability. This article focuses on the RBI, GoI initiatives, current status and future prospects of financial inclusion in India on the basis of facts and data provided by various secondary sources. It is concluded that financial inclusion shows positive and valuable changes.
\end{abstract}

Keywords: Financial Inclusion; Economic Status; Vulnerable Group; Banking Services.

Cite This Article: Dr. Mukesh Kumar Sharma. (2016). "FINANCIAL INCLUSION: A PRELUDE TO ECONOMIC STATUS OF VULNERABLE GROUP.” International Journal of Research - Granthaalayah, 4(12), 147-154. 10.29121/granthaalayah.v4.i12.2016.2403. 


\section{Introduction}

India is a country having more than 1.25 billion population, spread across 29 states and 7 union territories. There are around 6, 38,000 villages and 688 districts in the country. India is among the world's most efficient financial markets in terms of fundamentals, technology, regulation and systems. It is also having good saving rates in the world. Despite of it, poverty, misery, unemployment and financial exclusion continuously dominates socio-economic and political discourse in the country. Most of the population, especially in rural and tribal areas is excluded from the basic financial services. Access to safe, affordable credit and other financial services by the poor, vulnerable groups, disadvantaged areas and lagging sectors is recognized as an essential condition for accelerating economic growth, reducing income disparities and poverty. Easy access to a well-functioning financial system by creating equal opportunities, enables economically and socially excluded people to integrate better into the mainstream and actively contribute to development and protects themselves against economic shocks crisis .The Government of India (GoI) and the Reserve Bank of India (RBI) have been making concentrated efforts periodically to lessen such vicious problems by promoting and encouraging financial inclusion, being one of the important national objectives of the country. "Some of the major efforts have been taken in the past six decades such as: Nationalization of banks (1969and1980), Building up of Robust Branch Network of Scheduled Commercial Banks, Co-operatives and Regional Rural Banks (RRBs-1975-76), Introduction of Mandated Priority Sector Lending Targets, Lead Bank Schemes (1969), Formation of SHGs (1989-90), and Permitting BCs etc."1 The fundamental objective of all these initiatives is to reach to those sections of Indian population who have been financially excluded.

The financial inclusion means to bring disadvantaged and vulnerable sections of the society within the ambit of organized and standardized financial system. As per the version of Rangarajan committee, 2008 "financial Inclusion is the process of ensuring access to financial services, timely and adequate credit where needed by vulnerable groups such as weaker sections and low income groups at an affordable cost." 2 Financial Inclusion is mainly the combination of various financial services which are meant for the customers to give financial benefits. These financial services include basic banking, insurance, post office scheme, Micro finance, mortgage etc.

\section{Financial Exclusion}

Despite India's successes in the global economy, major sections of the population the poor, especially those living in rural and tribal areas - remain unaffected by this success, because they are unable to access financial institutions and therefore cannot take part in banking, borrowing, and saving. This phenomenon is known as financial exclusion.

"The word of financial exclusion first time used in 1993 by Leyshon and thrift who were concerned about limited access on banking services as a result number of bank branches were closed. In 1999, kempson and whyley defined financial exclusion in border sense which refers to those people who have excluded access to mainstream financial services and product till date numbers of analysts added their views to define financial exclusion.",3 
Financial exclusion is a serious concern among the low-income households, daily wage earners, bonded labors, as well as small businesses, mainly located in semi-urban, rural tribal areas. Basically, there is unavailability and unawareness of banking services to the people living in poverty and scarcity. It is opined that financial exclusion is the lack of access by certain consumers to appropriate, low cost, fair and safe financial products and services from mainstream providers.

There are mainly three types of financial exclusion:

- People who do not have any access to a regulated financial system;

- People who have limited access to banks and other financial services; and

- People who are unaware about the various financial products.

\section{Major Causes of Financial Exclusion}

Financial exclusion can make poor people vulnerable to loan sharks. It breeds poverty and hinders overall development of a country. It not only widens the "Rich-Poor divide", it also leads to "Social exclusion" There are various causes of financial exclusion which are being highlighted as below:

- Lack of banking facility in the locality (i.e. geographical exclusion including a ruralurban area)

- Financial illiteracy

- Casual attitude of the staff

- Complexity in documentation and procedures

- Unsuitable products

- Language Problem

- Uncomfortably in visiting a bank branch

- Lack of awareness, hesitant and initiatives in approaching a formal institution

- Low income/assets

- Distance from branch and branch timing

\section{Financially Excluders ${ }^{4}$}

The financially excluded sections generally are

- Marginal farmers

- Landless labourers

- Tribal people

- Urban slum dwellers

- Migrants

- Self-employed and unorganized sector enterprises

- Ethnic minorities and socially excluded groups

- Senior citizens and women 


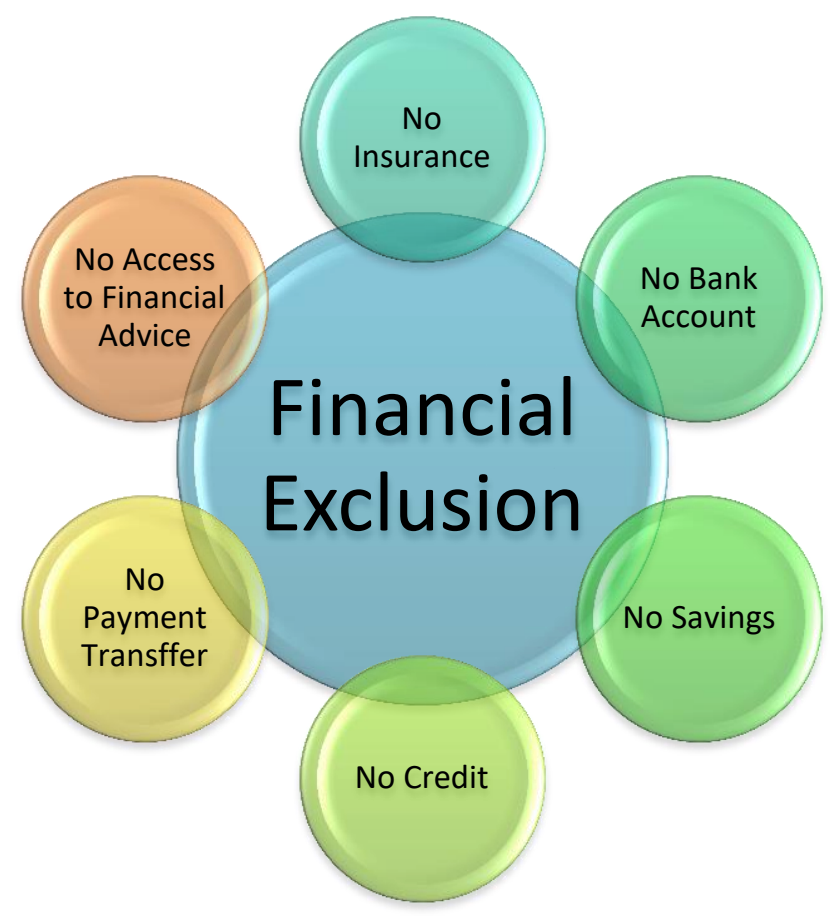

Attributes: Financial Exclusion

\section{Financial Inclusion and Its Importance for the Disadvantaged People}

Being able to access and use a wide range of financial products and services is now necessary 'to lead a normal social life " 5

"India is a country where a sizeable amount of population lives in rural areas. They are engaged in agriculture and allied activities. Most of the people living in rural areas are poor. They do not have any access to the banks. The access of the poor to the banking services is important for the alleviation of the poverty. Their access to the banking services will contribute a lot to the growth and development of our country's economy."6

This could be made possible through successful implementation of financial inclusion which involves the delivery of financial services at an affordable cost to the vast segments of low income and disadvantaged groups. The objective is to develop a model of an inclusive financial system which will support full participation of the neglected and unprivileged section of the society in the financial system.

Financial Inclusion has become a subject of considerable interest among policy makers, researchers and other stakeholders in recent times. The importance of financial inclusion for economic as well as social development has been well recognized across the nations by both economically rich and fiscally poor. It has also been recognized that access to financial services and education has a critical role in reducing abject poverty, boosting shared prosperity, supporting inclusive and sustainable development. It is therefore, there is no surprise that governments around the world are interested in finding effective approaches to improve the level of financial literacy amongst their population and that many are in the process of creating and 
implementing a national strategy for financial education to provide learning opportunities throughout a person's life. India has adopted inclusive growth as part of its economic planning. It was in fact that the 11th five year plan (2007-2012) which emphasized on inclusive growth and enables the vulnerable groups of the society to actively participate in the economic development of the country.

Financial Inclusion is a great weapon to overcome the financial backwardness as well as the establishment of good governance. It broadens the resource base of the financial system by developing a culture of savings among large segment of rural population and plays an essential role in the process of economic development and furthermore, by bringing low income groups within the parameter of formal banking sector. It protects their financial wealth and other resources in difficult circumstances. Financial Inclusion also mitigates the exploitation of vulnerable sections by the usurious money- lenders by facilitating easy access to formal credit. "The objectives of financial inclusion can be achieved through 5 A's which are."7

\section{5 A'S: Indicators of Financial Inclusion}

India needs to be conscious on poverty alleviation, especially among vulnerable groups; equitable economic growth through improvements in livelihoods, moderate employment opportunities, food security etc. Financial Inclusion encourages savings that promotes economic growth with productive investment. It promotes financial awareness and literacy of the rural masses and guides them to keep away from the expensive and unreliable financial services. This further helps the weaker group to invest their incomes into buying active and productive resources \& assets. In amidst of economic crisis, the rural economy can act as a support for the financial system. Hence, it helps in ensuring a sustainable economic growth in the country. It also supports economic efficiency, equity and self -reliance unrestrained access to public goods and which is an essential condition for an open and efficient society. Financial Inclusion is channelized mainly to provide affordable banking services to marginal farmers, landless labourers, Oral lessees, urban slum dwellers, migrants and unorganized sector enterprises, ethnic minorities and socially excluded groups, senior citizens and women etc. 
The importance of an inclusive financial system is extensively recognized in policy circles and has become a policy priority in many developing countries. Several countries across the globe now look at financial inclusion as the means for sustainable growth, wherein each citizen of the country is able to use earnings as a financial resource that can be put to work to improve likely financial status and adding to the nation's economic progress.

The major importance financial inclusion can be understood with the help of following points.

- It creates a base for inculcating saving habits among the people.

- It encourages savings which further promotes economic growth with productive investment.

- Bringing equitable economic growth with improvement in livelihoods, generating employment opportunities, food security etc.

- It promotes financial literacy among the rural section of the society and also helps them to avoid the expensive and unreliable financial services.

- It helps the weaker sections of the society to invest their incomes into buying active and productive resources \& assets.

- It helps in infusing gaps and leakages in subsidies and welfare schemes activities.

- During economic crisis, the rural economy can be a support system to stabilize the financial system. Therefore, it helps in ensuring a sustainable financial system.

- Direct Cash Transfer to Beneficiaries Accounts.

Table 1.1: Bank Group and Population Group wise Number of Functioning Branches from 2013 to March 31, 2015.

\begin{tabular}{|c|c|c|c|c|c|c|c|c|c|c|c|c|c|c|c|}
\hline \multirow{2}{*}{$\begin{array}{l}\text { Bank } \\
\text { Group }\end{array}$} & \multicolumn{3}{|l|}{ Rural } & \multicolumn{3}{|c|}{ Semi Urban } & \multicolumn{3}{|l|}{ Urban } & \multicolumn{3}{|c|}{ Metropolitan } & \multicolumn{3}{|l|}{ Total } \\
\hline & 2013 & 2014 & 2015 & 2013 & 2014 & 2015 & 2013 & 2014 & 2015 & 2013 & 2014 & 2015 & 2013 & 2014 & 2015 \\
\hline $\begin{array}{l}\text { Public } \\
\text { sector } \\
\text { Banks } \\
\end{array}$ & 23286 & 28907 & 29634 & 18854 & 22961 & 23549 & 14649 & 16967 & 17387 & 13632 & 15008 & 15325 & 70421 & 83843 & 85895 \\
\hline $\begin{array}{l}\text { Private } \\
\text { Sector } \\
\text { Banks }\end{array}$ & 1937 & 4082 & 4302 & 5128 & 6155 & 6457 & 3722 & 4320 & 4521 & 3797 & 4429 & 4698 & 14584 & 18986 & 19978 \\
\hline $\begin{array}{l}\text { Foreign } \\
\text { Banks }\end{array}$ & 8 & 8 & 8 & 9 & 12 & 12 & 65 & 57 & 57 & 249 & 245 & 247 & 331 & 322 & 324 \\
\hline $\begin{array}{l}\text { Regional } \\
\text { Rural } \\
\text { Banks }\end{array}$ & 12722 & 14281 & 14613 & 3228 & 3628 & 3748 & 891 & 1029 & 1071 & 166 & 205 & 228 & 17007 & 19143 & 19660 \\
\hline Total & 37953 & 47278 & 48557 & 27219 & 32756 & 33766 & 19327 & 22373 & 23036 & 17844 & 19887 & 20498 & 102343 & 122294 & 125857 \\
\hline
\end{tabular}

Source: Department of financial services, Government of India-2015 and Financial Inclusion in India (RBI Publications 2013) 
Table 1.2: The Present Status and Progress of PMJDY Scheme exhibited as under Pradhan Mantri Jan - Dhan Yojana (Accounts Opened as on 24.02.2016) (Figures in Crores)

\begin{tabular}{|l|l|l|l|l|l|}
\hline Bank Name & Rural & Urban & Total & $\begin{array}{l}\text { No of RuPay } \\
\text { debit cards }\end{array}$ & Aadhaar seeded \\
\hline Public sector Banks & 9.22 & 7.30 & 16.52 & 14.08 & 7.82 \\
\hline Private Sector Banks & .45 & .30 & .75 & .71 & .25 \\
\hline Regional Rural Banks & 3.19 & .53 & 3.72 & 2.67 & 1.10 \\
\hline Total & $\mathbf{1 2 . 8 7}$ & $\mathbf{8 . 1 3}$ & $\mathbf{2 1 . 0 0}$ & $\mathbf{1 7 . 4 6}$ & $\mathbf{9 . 1 7}$ \\
\hline
\end{tabular}

Source: PMJDY Government of India \{http://www.pmjdy.gov.in/account $\}$

\section{Interpretations}

Bank Group and Population Group wise Number of Functioning Branches from 2013 to March 31,2015 a highlighted in the table 1.1 which clearly indicate that progress in last three years is in increasing trend. Similarly table 1.2 Shows that the populations per office is decreasing trends year after year continually since 2008 - 2013, It was 15000 population per office in the year 2008, but in the year 2013, it shows that only 12000 populations per office. The scheme PMJDY playing a vital role in the development of financial inclusion in the country. Total number of bank account opened till 24-02-2016 is 21 crores which is a benchmark in the financial inclusion

\section{Conclusion}

For standing out on a global platform, India has to look upon the inclusive growth and financial inclusion. There is a long way to go for the financial inclusion to reach to the core poor. According to K. C. Chakraborty RBI Deputy Governor "Even today the fact remains that nearly half of the Indian population doesn't have access to formal financial services and are largely dependent on money lenders". Merely opening of no frill bank accounts is not the purpose or the end of financial inclusion while formal financial institutions must gain the trust and goodwill of the poor through developing strong linkages with community-based financial ventures and cooperative. India has made improvement in financial inclusion in the past few years, but IMF Financial survey shows that "India lags behind with other emerging nations in financial inclusion by a significant margin" ${ }^{\prime 8}$ Financial Inclusion has not yielded the desired results and there is long road ahead but no doubt it is playing a significant role and is working on the positive side to bring the economy on right path of the growth and development. Financial inclusion is not a onetime effort, it is an ongoing process. It is a big project which need concerted and team efforts from all the stakeholders such as financial institutions (public as well private), the regulators, private sector, Government and the community at large. The attempts spread across the nation and gained momentum and growth in Geometrical progression (GP). If the financial inclusion is to be achieved fully, it requires the passionate involvement, commitment and dedication of all the stakeholders involved. It further needs a major mindset change of every individual involved such as bureaucrats, bankers, regulators etc. and creating awareness at all levels. At the same moment, the role of technology cannot be undermined in the whole scenario. Awareness, accessibility, affordability, appropriateness, adequateness and benefits determine how financial inclusion penetrating the social fabric of the rural and tribals. Financial inclusion enables the 
poorest person and able to brings dramatic change in his fate. It is rightly said by Dr. Yunus that basic ingredient of overcoming poverty is packed inside each poor person. ${ }^{9}$ All we need to do is to help these persons to unleash this energy and creativity. Only place in the world where poverty will exist will be in the museums and no longer in human society." With combined efforts of all the stakeholders, viz; policy makers, regulators, banks, NGOs, MFIs and other similar entities, whole financial inclusion can be made possible in the country.

\section{References}

[1] Chabbra, Neeru (2014), Financial Inclusion in India, Ph.D. Report, MDU, Chapter-1,P-1 Retrieved from Shodhganga on 5-01-2016.

[2] Rangarajan, C. (2008), Report of the Committee on Financial Inclusion, National Bank for Agriculture and Rural Development (NABARD), Mumbai, January.

[3] Agarwal, Parul (2014), Financial Inclusion in India: a Review and Initiatives and Achievements, IOSR Journal of Business and Management, 16(6), June. P:52.

[4] Agarwal, Parul (2014), Financial Inclusion in India: a Review and Initiatives and Achievements, IOSR Journal of Business and Management, 16(6), June. P: 52.

[5] Gloukoviezoff, G. (2007), From Financial Exclusion to over indebtedness: The Paradox of Difficulties for People on Low Incomes? In L. Anderloni, M. D. Braga and E. M. Carluccio, Eds. (2007). New Frontiers in Banking Services: Emerging Needs and Tailored Products for Untapped Markets. Hamburg, Springer, 213-243.

[6] Roy, S. (2012), Financial Inclusion In India: An Overview, Asian Journal Of Multidimensional Research, 1(5), 134-141.

[7] Kumar A. \& Sheel, S. (2015),IDBI Operations in the Shade of Financial Inclusion, Raffles Business Review,1(1), 18-33.

[8] Nair R. (2012), India lags behind emerging nations in financial Inclusion, retrieved from http:// origin. www.Livemint.com/industry/zlkqb6dEHp9av /India-lags-behind emerging-nations-infinancial-inclusion.html.

[9] Yunus, Muhammad and Karl Weber (2007), Creating a World without Poverty: Social Business and the Future of Capitalisme, Public Affairs, New York. P: 223

*Corresponding author.

E-mail address: csmukesh88@gmail.com 